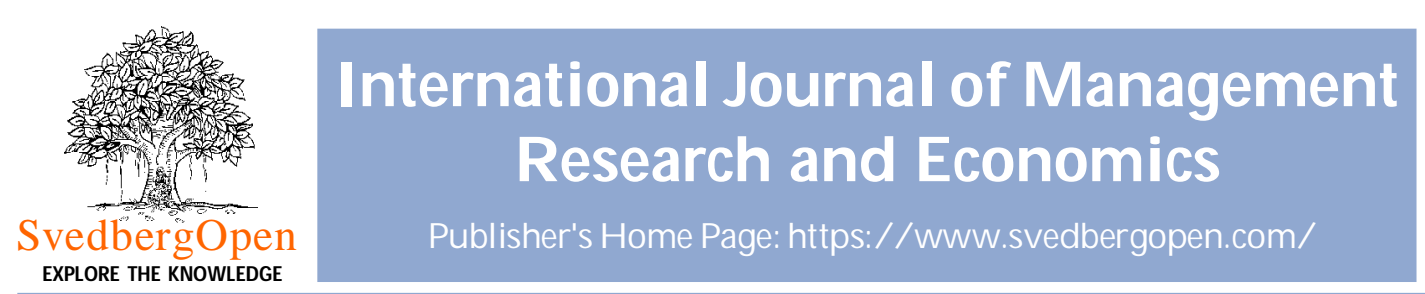

\title{
High performing institutions and economic development: A case study of Uganda
}

\author{
Olwor Sunday Nicholas ${ }^{1 *}$ \\ 'Independent Researcher, Kampala, Uganda. E-mail: sundolas@gmail.com
}

\section{Article Info}

Volume 1, Issue 1, January 2021

Received : 08 November 2020

Accepted : 15 December 2020

Published : 18 January 2021

doi: 10.51483/IJMRE.1.1.2021.34-58

\begin{abstract}
The study focuses on the related issues of the new institutional economics and political economy research: the evolution of formal economic and political institutions overtime; the causality between political institutions and economic institutions, and that between institutions and economic development; and the role of institutions in economic development. The issues are discussed in six sections. The study adopted the conceptual framework on institutions proposed by Douglas North that provide the basic scaffolding for human interactions, what he calls an institutional framework that nurture market exchange by lowering the cost of transacting, encouraging trust, and motivating the powerful to protect the property and individual rights of the weak. In Douglas North's view, institutions are the product of intentional human efforts to provide structure in an uncertain world. They reduce uncertainty and risks by making others' actions more predictable. Although many rules and habits change frequently, these fundamental institutions are more persistent and deeply rooted, which is termed the institutional environment or institutional framework. It has been noted in the study that a society's institutional framework is the product of its history. Powerful groups and individuals shape fundamental institutions to perpetuate their power, and some of these structures persist. They endure, and not just because powerful elites enforce them. Overtime they become part of society's shared beliefs about how the world works, or should work, beliefs about how others will behave, or should behave; they become internalized norms and can be difficult to change and impossible to ignore (North, 2005b). The study argues that despite pressures from the populace, political leaders and their interest groups holding de facto political power entrench themselves in the system under weakly institutionalized environment, and oppose reforms by all means including force, since such reforms go against their interests. The delay in such reforms often leads to the breakdown of governance. Such breakdown inevitably leads to conflict and social crisis such as the Buganda Crisis of 1966 and the related coup de tats that followed.
\end{abstract}

Keywords: Institutions, Development, High performing, Good governance, Sustainable development

() 2021 International Journal of Management Research and Economics. This is an open access article under the CC BY license (https://creativecommons.org/licenses/by/4.0/), which permits unrestricted use, distribution, and reproduction in any medium, provided you give appropriate credit to the original author(s) and the source, provide a link to the Creative Commons license, and indicate if changes were made.

\section{Introduction}

In his remarkable address to the Ghanaian Parliament on July 11, 2009, the US President Barrack Obama asserted that 'Africa doesn't need strongmen; it needs strong institutions.' He went on to refer to 'strong parliaments, honest police

\footnotetext{
* Corresponding author: Olwor Sunday Nicholas, Independent Researcher, Kampala, Uganda. E-mail: sundolas@gmail.com
} 
forces, and independent judges' as institutions that help to ensure that governments 'respect the will of their own people and govern by consent and not coercion.' Citing good governance as a key to prosperity, he added: 'this is about more than just holding elections. It is also about what happens between elections.'

In a similar vein, the United Nations recognizes that good governance is a vital ingredient in poverty alleviation and socio-economic development. The UN's Sustainable Development Goal No. 16 explicitly identifies 'effective, accountable institutions 'as essential elements in the development mix. Yet state capacity has been in short supply for too long in too many places. States with weak institutions can become havens for extremists, sites of humanitarian and human rights disasters, and a source of public health emergencies. Thus, even as development policy priorities evolve to address diverse aspects of human insecurity, there will always be a need for high-quality and high capacity institutions.

Recent years have seen a remarkable and exciting revival of interest in the empirical analysis of how a broad set of institutions affect growth. The focus of the recent outpouring of research is on exploiting cross-country variations in 'institutional quality' to identify whether a causal effect runs from institutions to growth. These papers conclude that institutional quality is a significant determinant of a country's growth performance. These findings are of fundamental importance for development economists and practioners in that they suggest that institutional quality may cause poor countries and people to stay poor. However, the economic interpretation and policy implications of these findings depends on understanding the specific channels through which institutions affect growth, and the reasons for institutional change or the lack thereof. One of the most pressing issues in comparative economic development literature is explaining the causes of economic development or the lack thereof countries across the world. This is particularly so for countries in Sub-Saharan Africa. First, a number of these countries have had poor development performance and outcome on average over the past five decades of post-colonial rule (Fosu, 2009), and they continue to face several major development challenges, which are not limited to, extreme poverty levels, low levels of social and private investment(both foreign and domestic investment), lack of resources to finance their development programs, corruption and recurring civil wars and conflicts (Aryeetey et al., 2012; AFDB, 2012; Blankenburg and Khan, 2012; Ndikumana and Boyce, 2011). Second, despite their economic hardships and the development gap, these countries continue to experience net outflows of financial resources to the developed world. These financial flows are claimed to be illicit and they are a result of political corruption, kickbacks, tax evasion, criminal activities, transactions of certain contraband goods, and other illicit business activities across borders (Reuter, 2012; Ndikumana and Boyce, 2011; Heggstad and Fjeldstad, 2010; Hollingshead, 2008). These financial resource outflows were estimated close to $\$ 1.4$ th over a 30-year (1980-2009) period have meant further deepening of underdevelopment as these countries continue to lose resources that could be used to finance their development goals (AFDB and Global Financial Integrity, 2013; Ndikumana and Boyce, 2011). This capital outflows puzzle could indicate that these countries are experiencing a saving glut.

North (1981) defines an economic institution as a 'set of rules, compliance and procedures and moral and ethical behavioral norms designed to constrain the behavior of individuals in the interests of maximizing the wealth or utility of principals'. Institutions are regarded as fundamental causes of economic growth (Acemoglu, 2003; Rodrik et al., 2002). The contribution of economic institutions to economic growth far outweighs the availability of natural resources, the supply of factors of production and technological progress (Acemoglu et al., 2001; Klomp and De Haan, 2009). Several reasons have been advanced for the importance of institutions in stimulating economic growth. One of the reasons is that economic and political institutions determine the incentives given to the main performers in the economy; the outcomes of economic processes are influenced by economic institutions. Through these incentives, economic institutions influence investment in physical and human resources, research and development, technology and the organization of production (Acemoglu, Johnson and Robinson, 2005; North, 1990; Weil, 2008). It is posited that economic institutions influence several aspects of economic outcomes, such as the distribution of resources. These resources are income, wealth, and physical and human capital. This means that economic institutions determine not only the aggregate economic growth but also the distribution of resources in the country and these in turn, contribute to maintaining order in the country.

It has also been argued that economic growth causes good institutions. Valeriani and Peluso (2011) acknowledged the bicausality between economic institutions and economic growth. The rationale for causality from economic growth to quality economic institutions stems from the simple logic that economic growth implies a high living standard with greater awareness. The higher the level of awareness is, the higher the sense of discipline and the demand for decency from the public. This demand for decency brings about high quality institutions, for example, the rule of law, property rights, good judicial practices, less harassment from the police and so on.

Given that these countries were once colonized by the European imperial powers, the issue is whether these developmental challenges are a result of institutions that were created during the colonial period, but which have 
persisted to the present day, and continue to affect their patterns of economic development. In other words, is the state of underdevelopment the aftermath of colonization which has had a persistent effect through its impact on the patterns of institutional development? This issue remains central in the literature on institutions and economic development literature (North, 1990; North and Thomas, 1973). This literature has advanced the institutional hypothesis that contends that the process of economic development or the lack thereof is primarily a function of the quality of economic and political institutions- the institutions whose roots are traced back to colonial rule (Acemoglu and Robinson, 2012; North and Thomas, 1973), who argued that the historical fact of being colonized by Britain for example, rather than any of the other colonial powers, has a strong effect on the legal system of the former colonies and, through that, on economic development. Institutions in this context, are understood to be a composite of norms and rules that govern human interactions and the enforcement thereof (North, 1990, 1993). On the one hand these institutions are said to include formal rules such as the laws that protect private property rights, the enforcement of the rule of law, and the protection and respect of peoples' political and civil liberties. On the other hand, they are claimed to include informal rules that comprise habits, beliefs, social cleavages, traditions and norms (ibid.). It is argued that these institutions provide the overall incentive structure that supports markets, that channel individual economic efforts into economic activities that bring the private rate of return close to the social rate of return, and that enable trade and exchange to take place to increase the economy's productive capacity (Acemoglu and Robinson, 2012; Banerjee and LYER, 2005; North and Thomas, 1973). In one of his landmark contributions to this literature, North (2006) further claims that development (economic change) depends largely on 'adaptive efficiency', of the country's institutional matrix. The concept of adaptive efficiency, he explains, relates to society's capacity and capability to create institutions that are productive, stable, fair, and broadly accepted-and, yet sufficiently flexible enough to be changed or replaced in response to exogenous shocks or to growing tensions inherent in society's development. Therefore, according to him, different societies create the institutional infrastructure that greatly determines their economic development trajectories (North, 1993, 1990; Acemoglu et al., 2001, 2003).

Relying on North's conception of institutions, this literature suggests that developing countries, in particular those in Africa, and Uganda inclusive, failed to develop because they didn't create the development-promoting institutional structures of the type created by Western Countries or, where they were created, they were either weak, or poorly devised and implemented. This literature further argues that the State in each of these countries was either too weak to act as a guarantor of rights and institutions or much too predatory in its own demands, posing a threat to them (Bardhan, 2001). In contrast, Western societies developed because they established the incentive creating institutions that constrained behavior of participants in the markets (that is, economic markets and political markets); that reduced uncertainty in social interactions through the protection of property rights; that limited agency costs and rent seeking; and in general, that prevented excessive transaction costs in markets. The transaction costs are understood in this context to include the cost of making exchange, cost of contract enforcement, and the information costs (Coase, 1992, 1988). All these costs are said to affect not only contractual arrangements but also what is produced and exchanged, and the size and activities of the whole economy (Coase, 1992). At the same time Western countries had strong states that had credible commitment to enforcement of rule of law and were less predatory. In consequence, these countries realized productivity gains from larger scale and improved technology that stimulated their economic development. The empirical evidence evolved in support of the institutional hypothesis that institutions matter for economic development. The hypothesis emerged in the early classical papers starting with those by Barro (1996, 1991), Keefer and Knack (1995), Hall and Jones (1999) and Acemoglu et al. (2001). Later studies by Rodrick et al. (2002); Kaufmann and Kraay (2002) and Easterly and Levine (2003, 2001), also produced evidence in support of this hypothesis.

In contrast to the New Institutional Economics strand of literature, there are other competing views on the main causes of lack of economic development among African countries. These include the 'government policy failure hypothesis' and the 'geography hypothesis'.

\subsection{Research questions and the contribution of the study to the literature}

Despite theoretical and empirical contributions and insights from this literature, a number of important but challenging research questions remain to be explored in this broad research agenda. These basic questions are: How do institutions evolve across time and space? To what extent have the institutions established during the colonial period persisted to the present day? Why have they persisted? Do political institutions determine economic institutions? How and to what extent have these institutions impacted on the process of economic development of the former colonies at individual country level? Is the continued net outflow of financial resources a result of weak political institutions that were established during the colonial period but persisted to the present day? Are they rather a reflection of broader postindependence institutional failures? To what extent do such institutions (that is, property rights institutions) continue 
to affect the process of investment (either domestic or foreign investment) of the former colonies in Africa? Understanding these issues remains crucial for paving the new developmental path for African States and continues to warrant attention in both academic and policy discourse.

As part of this discourse, this dissertation explored some of the foregoing research questions of the broader new institutional economics and political economy research agenda. This research sought to avoid the caveats of the literature highlighted above. The dissertation focused mainly on three related issues: (i) the evolution of economic institutions and political institutions across time and space; (ii) the causality between institutions and economic development outcomes, and between political institutions and economic institutions; and (iii) the role of institutions in economic development through the channel of foreign direct investment and the control of rent seeking and corruption.

The research made use of the conceptual framework on institutions proposed by Douglas North. This framework relaxes the neoclassical assumptions of perfect information, zero transaction costs and perfect rationality. This framework put emphasis on the role of legal institutions - both property rights institutions and political institutions on economic development outcomes. These issues have been discussed in four chapters in the main dissertation. The dissertation is mainly focused on Uganda as a case study and the motivation for choosing so has been explained.

\subsection{The study conceptual framework}

This study adopted the conceptual framework and definition of institutions postulated by Douglass North. This was the view that institutions are 'the rules of the game in a society or... Humanely devised constraints that shape human interactions' in the economic, social and political spheres (North, 1990). These comprise both the formal rules (constitutions, laws and regulations) and informal constraints, such as norms of behavior, and self-imposed codes of conduct. However, this dissertation is concerned more with formal constraints and takes a more macro-analytic perspective. This approach is more pertinent for economic development and reform (Williamson, 2000). It considers the political and legal rules of the game and the institutions of governance. Thus, it places emphasis on those factors that shape the institutional environment. This macro-analytic approach finds support from Williamson (2000) who argues that 'although the institutional economics strand of principal interest is mainly with macro-analytic matters, there would be much less incentive to turn to the micro-analytic approach had been more successful (Williamson, 2000).

Within this framework, institutions can be divided into two broad groups following Acemoglu and Robinson (2012): the inclusive institutions and extractive institutions. This division applies to both economic institutions and political institutions. That is, inclusive economic institutions and the exclusive political institutions, and the extractive economic institutions and the extractive political institutions. This dissertation proposal adopts an operational definition of 'inclusive economic institutions' of Acemoglu and Robinson (2012) who define them as those institutions that: (i) protect private property rights; (ii) judicial and contracting institutions that uphold contracts and enable individuals to enter into mutually beneficial agreements. More importantly, these institutions are seen to provide a level playing field by ensuring that individuals are not prevented from entering into businesses and choosing options that are best for themselves. Accordingly, these authors make a compelling argument that broad-based political institutions are a prerequisite for building the kind of economic institutions from which growth can translate into sustainable development.

\section{Literature review}

Stiglitz and Hoff (1999) asserted that 'in leaving out history, and distributional considerations, neoclassical economics was leaving out the heart of development economics'.

The literature from economic development emphasizes the importance of property rights institutions and political institutions in the process of economic development (Acemoglu and Robinson, 2012; Rodrik et al., 2002; Easterly and Levine, 2001; Acemoglu et al., 2001; Engerman and Sokoloff, 2000; North, 1990). It claims that property rights and political institutions are important because they provide the basic economic incentive structure that stimulates investment in the key development enhancing variables. These include human capital, physical capital and technological change. Institutions in this context are defined as the rules in a society that are devised to constrain human behavior and shape the interactions between agents in the economy. They comprise both formal rules (that is, laws, constitutions) and informal constraints (that is, customs and traditions). This literature further claims that the enforcement of these rules is important to realize the desired economic outcomes (Aron, 2000).

Researchers such as North (1998); Rodrik et al. (2002) and Petrunya and Ivashina (2010) have shown that economic institutions are primary causes of economic growth, far more than the natural environment, the supply of factor inputs and technological progress. Economic institutions that are important for growth include those that protect property 
rights (Acemoglu et al., 2001; North and Thomas, 1973); those that mobilize savings and make them available for investment (Tchouassi, 2014) and those that cause rulers to be subjected to the ruled or hold the rulers accountable to the majority of people (Acemoglu and Robinson, 2012; Keefer, 2005).

Przeworski and Curvale (2007) stated that economic institutions that promote economic growth are institutions that absorb, and peacefully process likely conflicts of interests and values under any conditions. These institutions are political and they must be self-sustaining. The solution that is attained using these political institutions should be preferred to the solution that would be achieved through the use of force by each of the parties involved.

Acemoglu et al. (2005) argued that economic institutions determine the long run causes of economic growth. Adam (1776) once put forward the same argument. Acemoglu et al. (2005) concluded that the traditional neoclassical economic growth models of Solow (1956), Swan (1956), Cass (1965) and Koopmans (1965) explained differences in per capita income across countries in terms of differences in capital accumulation. In these models, cross-country differences in factor accumulation are explained by differences in saving rates (Solow 1956; Swan, 1956), preferences (Cass, 1965; Koopmans, 1965) or other exogenous parameters like the total factor productivity or technological progress.

These models accept that institutions do exist. The models are based on representative agents who are assumed to be well behaved and have property rights and agents exchange goods and services in the markets. However, the models don't acknowledge that differences in income and growth rates are not explained by differences in institutions or variations in institutions. Acemoglu et al. (2005) acknowledge the emergence of the first wave of later growth theories of Romer (1986) and Lucas (1988), which are different from the frameworks of the neoclassical growth theories. They emphasized that these are different in the sense that the new theories emphasize that externalities from physical and human capital accumulation have the tendency to sustain unlimited, steady state of growth or long run per capita growth rates. Acemoglu et al. (2005) further argued that this approach remains within the neoclassical tradition using preferences and endowments to explain long run growth.

The second wave of the growth models, particularly those of Romer (1990), Grossman and Helpman (1991), Aghion and Howitt (1992) and Barro (1990), endogenized economic growth and technological progress. However, their explanation of differences in per capita income across countries is in tandem with those of the neoclassical school and the first wave of endogenous growth models. Romer (1990) argued that one country may grow faster than another country by investing more resources in research and innovation. Barro (1990) argued that a country may prosper by making sure that public goods grow at the same rate as the growth rate in private investment per labor head.

Romer (1990) didn't explain what determines the preferences and the prospect of the technology for creating ideas. Barro (1990) didn't explain what causes government to expand the provision of services in line with the growth rate of capital per labor head.

The neoclassical and endogenous models have become the traditional tools for economic growth explanation (Acemoglu et al., 2005). This traditional approach provides insight into economic growth mechanisms. However, Acemoglu et al., 2005 argued that the approach has failed to explain the fundamental cause of economic growth. This is the reason North and Thomas (1973) posited that innovation, technology, human capital development, physical capital, economies of scale and government provision of services are growth in itself and they cannot explain growth.

The arguments in favor of institutions in promoting economic growth are many. Economic institutions matter for economic growth because they influence the incentives for the key performers in the economy (Easterly, 2008). To be more specific, economic institutions influence investments in physical and human capital, technology and the organization of production (Acemoglu et al., 2005). It is further suggested that geographical and cultural factors also matter in terms of economic growth, but that institutions are not only significant in explaining long run economic growth (Weil, 2008). Institutions are not only significant in explaining aggregate economic growth, but they are also important in explaining an array of economic outcomes, such as the distribution of resources (wealth, physical capital and incomes). This means that economic institutions also influence how economic wealth is distributed among members of society, be it output, income, physical capital or human capital (Acemoglu et al., 2005). Based on this, it can be contended that economic institutions determine the economic performance and distribution of resources in a society.

\subsection{Theory of evolution of economic institutions-property rights}

This section provides a brief discussion on the evolution of institutions. It summarizes the different theories that have developed to explain how property rights institutions evolve and change. The influence of political forces on property rights institutions was first discussed in the early works of Knight and recently revived in the works of Acemoglu and Robinson (2006, 2008). 
The evolution of property rights was explained succinctly by the early scholars such as Harold Demsetz who is said to be the founder of efficiency theory. This theory asserts that private property rights emerge as a result of increasing values in land which consequently leads rational economic agents to creating institutions that secure property rights (Demsetz, 1967). The theory makes a simplifying assumption that such rising values would always lead to universal preferences for private property rights. It argues that such preferences occur because, with rising land values, the potential gains from land transactions grow. However, under an environment of insecure property rights such gains are impeded. This is because an environment with secure property rights is characterized by increasing transaction costs which include costs of enforcement — an issue that was advanced by Ronald Coase and his followers in later writings (Coase, 1937, 1988; Hart and Moore, 1990).

The efficiency theory, however, made an overly optimistic assumption that as land value rise, rational actors will create institutions that create security of property. This assumption was subjected to criticisms by the political revisionism and new institutionalism theorists following Douglas $\mathrm{C}$ North. The basis for this criticism has been the observed existence of insecurity of property rights in some countries despite rising property values. It is also based on the omission of information of how institutions evolve and change across time and space (Knight, 1992). According to the political revisionism thesis, property rights institutions evolve as a result social conflict among actors with different and incompatible goals. In this view, "institutions are a product of the efforts of some to constrain the actions of others with whom they interact". Thus, private property rights institutions are a reflection of the instruments of those in superior bargaining positions. However, although this thesis acknowledges the collective benefits that often result from institutional innovations, it asserts that such benign occurrences are incidental. The revisionists view further asserts that low quality institutions will persist if rulers are unwilling to anger those powerful constituents who benefit from the status quo. In conclusion, this thesis affirms that everyone would want secure property rights institutions and the lower transactions costs associated with them but the rulers are not willing to create such institutions because of self-interests.

The revisionists therefore propose that conflict and the extension of bargaining power are of primary importance for understanding the evolution of institutions and institutional change (Knight, 1992). Acemoglu and Robinson (2008); Robinson (2010) support this earlier views and show indeed the equilibrium that economic institutions emerge from interaction between political institutions, which allocate de-jure political power, and the distribution of de-facto political power across social groups. De-facto political power is that which is not allocated by institutions (such as elections), but is possessed by citizens/groups as a result of their wealth, weapons or ability to solve the collective action problem.

The new institutionalism literature adds that evolution of low quality institutions and their persistence are principally a result of incentives for corruption and lack of institutional capacity of the ruling authorities to create and maintain better quality institutions (North, 1993). Thus, incentives for corruption by leaders is viewed in this context as a hindrance to the evolution of better quality institutions that secure property rights for everyone. The supporters of new institutionalism assert that due to the path-dependence characteristics of institutions, the reforms that could improve the quality of institutions are hard to implement.

\subsection{Empirical studies on institutionalism and economic development}

Empirical literature is presented in this section. Lehne, Mo and Plekhanov (2014) researched the determinants of the quality of economic institutions in cross-country settings. The study was based on the observation that the relationship between a good political system and economic growth is not linear but a 'U'-shaped curve. The study listed democratic institutions, geography, history, ethnic factionalism and natural resource endowments as the determinants of resources in society.

Using appropriate measures of some factors affecting economic institutions, the study found that democracy improved economic institutions and that history had a significant impact on economic institutions. Other findings were that geographical factors such as economic openness and resource abundance had a substantial impact on economic growth. The study further found that resource abundance tends to encourage bad economic institutions.

Okoh and Ebi (2013) examined the impact of infrastructural development and the quality of economic institutions on economic growth in Nigeria. In estimating the impact of corruption and infrastructural development on economic growth, several specifications were used to test the robustness of the results. The results generally showed that infrastructural development and contract enforcement had a positive and significant effect on economic growth. Corruption exacted a negative effect on economic growth.

Valeriani and Peluso (2011) investigated the institutional framework under which economic growth takes place and how economic institutions explain growth and differences of growth across countries. The regression model used by the study stated that economic growth is determined by education (EDU), infrastructure (INFRA), dummy variables 
(representing economic institutions) and regions (REG). The results of the study showed that the quality of economic institutions impact positively on growth. The study also showed that investment stimulated economic growth.

Tamilina and Tamilina (2014) explained the uniqueness of economic institutional effects on economic growth in postcommunist countries. Their study showed that the collapse of communism in the communist countries led to radical changes in political, social and economic systems of the former communist countries. The introduction of capitalist economic institutions was dysfunctional (Polterovich, 2008). The relationship between the quality of economic institutions and economic growth in the former communist countries appeared to differ from the patterns in advanced and developing countries. The study revealed that the revolutionary process accounted for the poor functioning of the former communist economic systems.

The study found that economic institutions that are evolutionary, affected economic growth in relation to their quality ratings. Good economic institutions promoted growth. In revolutionary methods, the effect of the quality of economic institutions on growth does not reflect their index in the short run, but in the long run they do.

Davis and Hopkins (2006) investigated the interaction between economic institutions, inequality and economic growth. The study was designed to establish whether economic institutions stimulated economic growth. The study was also designed to test the hypothesis that inequality does not stimulate economic growth positively. The statistical analytical method employed five yearly sets of data for eight periods starting from 1961/1965 to 1996/2000. It employed a regression model which stated that the per capita income is a function of years of schooling plus the Gini coefficient representing inequality, plus a variable for economic institutions which is property rights. The results of the study showed that economic institutions promoted growth but that income inequality depressed growth. The study further demonstrated that investment also promote economic growth.

Zouhair (2012) studied the effects of institutional factors on investment and growth in the Middle East and North America. The study covered 11 countries for a 9-year period from 2000 to 2009 and made use of dynamic panel data. The theoretical perspective of the study emphasized the fact that the empirical impact of institutions on economic growth is increasing since the seminal work of North (1991). Good economic institutions encourage economic agents to invent. Conversely, poor institutional quality creates uncertainty, unpredictable environments, instability and corruption and thereby increasing the cost of transacting. In such an environment, private investments are discouraged and thus retard growth (Zouhair, 2012).

The estimation of the model applied in the study used the Generalized Method of Moments (GMM) of Arellano and Bond (1998). The key findings of their study showed that political institutions and investment stimulated growth. The study also showed that interaction between political institutions and investment promoted growth, while instability depressed growth.

Docquier (2014) identified the impact of institutions on economic growth. The study stated that the past century had come and gone but only a few poor countries had caught up with the rich countries. The study was designed to explain convergence across countries. Data used for the study spanned from 1870 to 2010. It found no evidence of convergence of economic institutions among countries studied and didn't find any evidence of convergence in growth.

Ferrini (2012) examined the interaction of economic institutions to stimulate economic growth. This is achieved through considering four aspects of economic institutions. The first aspect is the reduction in the costs of economic transacting (exchange). Economic institutions enhance development by encouraging people to enter into contracts. Contract enforcement uses common commercial law codes and the sharing of information. This reduces transaction costs, risk and uncertainty. Secondly, economic institutions determine the degree of appropriation of returns to investment. Property rights, fundamental human rights, and the rule of law encourage investment, employment, output and incomes. Thirdly, economic institutions determine the expropriation of state resources by the ruling elite. Unequal opportunity provided by economic institutions discourages investment and economic exchanges. Fourthly, economic institutions determine the degree to which the investment environment is conducive to cooperative behavior and this increases social capital. Inclusive and participative economic institutions increase the free flow of information and the extent to which resources can be pooled and invested in collective properties (education, health and infrastructure), reduce risks and ensure sustained wealth creation.

Pereira and Teles (2009) employed an econometric model based on the GMM and used the autoregressive distributed lagged model for 109 countries for a 9-year period, from 1975 to 2004. The key dependent variable was the GDP per capita; political institutions were taken as explanatory variables. The political institutions used were the electoral rules (plurality versus proportional representations), form of government (parliamentary versus presidential systems) and political regime (dictatorship versus democratic leaders). When economic variables were controlled or moderated, the 
study demonstrated that political institutions matter for recipient democracies, and not for consolidated democracies. Consolidated democracies have already internalized the effects of the political system on their economic growth. In recipient democracies, there is a need to internalize good political institutions that will promote economic growth to ensure the continued growth of the economy.

Looking across countries, the literature argues that improvements in the quality of contracting institutions, better law enforcement, increased protection of private property rights, improvements in central government bureaucracy, improved operation of formal sector financial markets, increased levels of democracy, and higher levels of trust are all correlated with higher economic growth. There is also widespread recognition of the fact that institutional form may be determined by economic performance. The key instrumental variables that have been examined in many literatures are based on geography (distance from the equator and predicted trade share, oil exporter) and colonial and pre-colonial history (settler mortality, legal origin, ethnic and linguistic composition, pre-colonial population density, state antiquity). The paucity of plausible instruments arises from the fact that there are few variables that are important determinants of the current form of a particular economic institution but affect growth through that institution.

Another striking feature is that the same variable is often used in different studies as an instrument for different indices of institutions, and interpreted in varying ways. Consider settler mortality. It is used to instrument for: (i) protection against expropriation risk; (ii) executive constraints; (iii) measures of financial depth such as private credit; (iv) a rule of law index; and (v) the overall index of institutional quality.

\subsection{Measures of institutions and institutional change}

It should be noted that measuring institutions turns out to be more difficult than it sounds. Economists have put considerable effort into defining and testing institutional variables for cross-country growth regressions, but far less effort has gone into measuring institutions in specific countries. Specificity is crucial because as North et al. argue, the same institutions work very differently in limited access and open societies. Because they lack specificity, few current institutional measures are what Steve Knack calls 'actionable', that is, able to help researchers analyze the causal effects of specific institutions, help citizens demand better institutions and hold leaders accountable, help reformers design successful and sustainable improvements in institutions, and help aid-givers judge when countries are able to use aid more effectively (Knack, 2006).

Many cross-country regressions persistently demonstrate large and statistically significant correlations between institutional variables and growth in GDP per person. Specifically, growth in GDP per capita is significantly and positively correlated with (i) protection of property rights and enforcement of contracts; (ii) measures of economic freedom such as voluntary exchange, free competition, and protection of property rights; (iii) civil liberties; (iv) political rights and democracy; and (v) institutions supporting cooperation, such as trust, religion, and social clubs and associations. Growth is negatively correlated with political instability, defined as coups, revolutions, riots, and deaths from political violence. Political instability is treated as a proxy for weak institutions to mitigate conflict and promote civic order, such as the absence of law and norms prompting people to express their grievances peacefully. These institutional measures have large and significant correlations with growth even when different measures from different sources are used, including voice and accountability, regulatory burden, rule of law, graft, constraints on executive power, or property rights (IMF, 2003). Furthermore, in horse races between variables an index of institutional quality 'trumps' measures of geography or trade as an explanation for levels of development, although geography and trade also have effects on institutional quality (Rodrik et al., 2002).

However, some critics argue that high scores on civil liberties, rule of law, democratic politics, secure property rights, enforcement of contracts, political stability, cooperative social norms, and trust are the definition of development. In contrast, proponents view these variables not as institutional outcomes, but as measures of institutional quality (Rodrik et al., 2002) or 'clusters' of institutions (Acemoglu et al., 2005). Some propose 'unbundling' institutions, by separating the effects of, for example, property rights institutions and contracting institutions (Acemoglu and Johnson, 2005), but even these unbundled institutions are still broad abstractions mediated by the presiding political power in the country.

\subsection{Research gaps and criticisms of existing literature}

The contributions and insights from the New Institutional Economics literature have contributed insights on economic development. However, there are limitations to this literature and some research gaps that still warrant attention. The basic limitation of this literature has been its exclusive use of cross country econometric analyses with less attention given to country case studies to prove the importance of institutions for economic development. For instance, Rodrik (2008) notes that the evidence provided by such analysis is uninformative because it ignores the influence of institutions (economic and political institutions) at a country specific level despite the recognition that developing countries are 
different from advanced economies. He notes further that because countries are heterogeneous, the kind of institutions that work in one country might not necessarily work in another. Developing countries might need 'appropriate' institutions. By 'appropriate institutions' he refers to those institutions that are country and context specific. In addition, Rodrik (2007) argues that while competitiveness-enhancing institutions have same functions across economies-namely, the protection of private property-their form is context specific, and history dependent.

Chang (2011) endorses Rodrick's argument and notes further that given that the relationship between institutions and development is almost certain to differ across countries, 'time-series' evidence may offer better further that such evidence should also not be confined exclusively to econometric analysis, which cannot capture complexities that characterize the domain of institutions, but should include historical narratives and comparative historical studies. In the light of the foregoing arguments, an exploration of the influence of institutions on econometric outcomes at the country level is warranted.

Although the NEI literature has suggested the need to understand the formation and evolution of institutions across time and space to understand the process of economic development (North, 1993, 1990; North et al., 1971), the studies that attempt to do so are limited. This omission was noted earlier by North in his seminal works as is reflected in the following extract: 'although Ronald Coase made the fundamental contribution of pointing out that when it is costly to transact, institutions matter, neither he nor most of his followers have explored how property rights and other institutions came about'. Bardhan (2001) corrobates North (1993) and notes that 'it is clear that the literature has barely scratched the surface of an as yet largely unexplored story in poor countries. Particularly lacking are the theoretically informed, inductive, historical analysis of institutional evolution and change or atrophy in these countries of the kind Greif has so incisively carried out for late medieval Europe. North has further emphasized the need to first understand the stability characteristics of institutions, and the interaction between political institutions and economic institutions in order to understand institutional change'.

Despite this oversight, the literature has at least advanced the notion that the current institutions in the former colonies were shaped by their colonial history. This notion has been popularized by Acemoglu et al. (2001) who develop an elaborate argument based on the colonial legacy of former colonies. Specifically, these authors postulate that European colonizers established institutions that were not conducive for investment and development (that were extractive, in Acemoglu and Robinson's (2012) terminology in places where they could not settle because they faced high mortality rates. They contend that such extractive institutions didn't foster the process of economic development. In places where they settled because they faced lower settler mortality rates, they created durable institutions (inclusive institutions) that were conducive for private investment and thus promoted economic development.

Criticisms of this literature lies in its omission of the channels through which institutions affect the process of economic development, and in identifying a set of institutions important for economic development at country level. In one of their often cited papers, Acemoglu and Johnson (2003) argue that while there is considerable evidence that institutions are important determinants of economic and financial outcomes, there has been relatively little work investigating which types of institutions matter for economic outcomes. This study will offer a step in that direction.

In addition, the evidence presented by the institutions-development literature has often been criticized for using conventional institutional indicators (the Heritage Foundation Index of Property Rights, the International Country Risk Guide which measures property rights and investors' protection, and Polity IV Measures of Political Institutions) that are claimed to be suspect. For instance, Glaeser et al. (2004) criticize these measures on the grounds that they measure outcomes and not permanent characteristics of institutions as postulated by North (1990). These authors further claim that these indicators rise with per capita income and are highly volatile and thus are poor measures of permanent or even durable features of institutions. This dissertation will contribute to the institutions and development literature by providing a new set of institutional indicators that circumvent these weaknesses.

\subsection{Summary}

Review of cross sectional studies above with respect to the impact of institutions on development outcomes leads to the following conclusions: a wide similarity in defining institutions; stress on the importance of institutions for growth and development; disagreement on the relative importance of the various institutions; and concerns about causalities, methods and channels of influence.

First, nearly all the quoted studies use a proxy for institutions proxy variables and variables that measure the quality and performance of institutions rather than the institution itself. The strength of the rule of law, risk of expropriation and the security of property rights are mainly the outcome of the institutional set up of the country. In some literature there 
is a tendency to prefer this kind of variable in growth regressions over variables that instead describe attributes of political institutions and society for political instability (Aron, 2000).

Second, there is an overall acknowledgement that institutions matter and have a direct impact on growth. For example, Rodrik et al. (2002) found that the 'estimated direct effect of institutions on incomes is positive and large'. Besides an observed direct impact, most studies also acknowledge an indirect impact on growth and economic development. Institutions can lead to an increase in investment, to a better management of ethnic diversity and conflicts, to better policies and to an increase in the social capital stock of a community. All these factors have a recognized positive influence on growth. Therefore, most of the studies suggest a strong and robust relationship between institutional quality and growth and development outcomes.

Third, there is a disagreement and a continuous debate on the relative importance of institution in particular vis-à-vis trade and geography. There is an ongoing debate between a group of researchers headed by Dani Rodrik and another centered on Jeffrey Sachs. Whereas the former stresses the dominant importance of institutions, the latter puts geography as the most important factor explaining differences in growth rates. Finally, Dollar and Kray (2002) puts most emphasis on the role of being integrated into the trade system. Besides the dispute about the relative importance of institutions, the channels of influence are also controversially debated. The simultaneous relationship between growth, investment and institutions makes it difficult to find out the relative importance of the indirect and direct effects.

Finally, most authors acknowledge the existing deficits of cross-sectional studies. The identified weaknesses relate to problems of definition, causalities and the proper interpretation of findings. In a very careful literature survey, Aron (2000) reaches to the conclusion that 'interpreting the evidence on growth using institutional measures is not a straightforward matter'.

Key limitations of relying on cross country studies are the following. First, there is no consensus what kind of variables ought to be included or left out. High quality institutions could entail the protection of property rights, low risk of expropriation, a well-functioning judiciary system, political stability, a high stock of capital and so on or a mixture of these indicators. Hence, the aggregation of the indicator presents a problem as every element might influence income in a different manner. Secondly, there is the risk that the analysis becomes tautological when institutions are per definition of a high quality. The point here is that it is quite reasonable to expect that political stability positively contributes to growth, however, the more interesting question is what kind of institutional arrangement lead to political stability. Third, institutional quality is often measured in terms of the perception and views of foreign investors and experts. These data are regularly collected and updated in the ICRG and the BERI. This approach is probably very valuable for developed countries but not necessarily for developing countries as these evaluations focus mainly on aspects of formal institutions, whereas in most low income countries informal institutions are of critical importance. One can have doubts on whether non-resident experts and investors have sufficient information to make sound judgment on this subject when applied to a case study of Uganda.

\section{Findings and discussions}

It is asserted that once a set of institutions comes to dominate society it tends to persist for long periods of time though the institutional path can certainly change in the context of major critical junctures. ${ }^{1}$ The literature on institutions and economic development has advanced three main propositions. First, those institutions that were established by the European Imperial powers in their colonies during the colonial era have shaped the current state of institutions in these former colonies. Second, that such institutions have had lasting effects on these countries' economic development even though these countries attained their independence from the European colonial powers several decades ago. ${ }^{2}$ Third, that political institutions in particular, are the main causes of these countries' development problems. ${ }^{3}$

The first proposition also dubbed 'the persistence of institutions hypothesis' ${ }^{4}$ is understood in this context to refer to the possibility that the effects of institutions may persist over long time spans even after those specific institutions have long been changed or evolved in some way. In Robinson (2010)'s parlance argument goes like: "Once a set of institutions comes to dominate a society it tends to persist for long periods of time though the institutional path can certainly change in the context of major critical junctures". This proposition finds its basis in the seminal works of Acemoglu et al. (2010); Engerman and Sokoloff (2000). According to these authors, European colonizers established institutions that were not conducive to investment and development (they were extractive, in their terminology) in

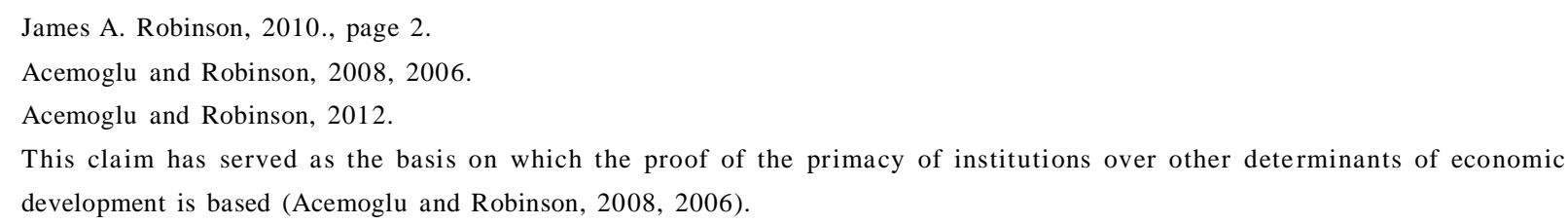


places where they couldn't settle because they faced high mortality rates. Such extractive institutions didn't foster the process of economic development and have persisted to the present day, and continue to stifle the process of economic development of these former colonies. While in countries where colonizers settled because they faced less settler mortality rates, they created durable institutions that were conducive to private investment and promoted economic development. Notwithstanding its general acceptance, this proposition has neither been empirically tested, nor discussed from a historical perspective in the context of these former colonies, in particular in Africa. ${ }^{5}$

The assumption of institutional persistence has also given rise to a number of other important research questions that have remained outstanding in the institutions-development discourse as emphasized by Acemoglu and Robinson (2008). For instance, why are some rules persistent while others are not? Why do some political leaders create and strengthen institutions that promote long run economic development, such as security of property rights while others neglect such institutions or destroy those that already exist? The current development discourse has been grappling with these questions, especially for developing countries.

The second claim is that institutions have stifled the process of economic development of the former colonies. This claim suggests that there is causality running from institutions to economic development in these countries. This claim has remained controversial in the literature. The controversy arises with regard to whether causality is unidirectional or bidirectional. One view from the literature asserts that it is institutions that drive the process of economic development. According to the proponents of this view, political institutions such as democracy and other checks and balances on government are the main mechanisms for securing property rights that eventually stimulate investment in human and physical assets, and therefore economic growth and development. They assert that differences in economic performance of countries around the world are due to colonial rules that created completely different institutional development trajectories. Acemoglu et al. (2001) view institutional development as a causal mechanism through which colonial institutions influences economic development. The burgeoning empirical works that support this view often assume unidirectional causality. That is, they assert that causality runs from institutions to economic development, ignoring the possibility that economic development could change institutions. A contrasting view in the literature following the seminal works of Lipset (1959) ${ }^{6}$ argues that it is development that leads to better institutions (Chang, 2011, 2006). ${ }^{7}$ According to this line of argument, a minimum threshold level of economic development and human capital is the basic requirement necessary to sustain democratic institutions and economic institutions. The proponents of this line of thinking further posit that such a minimum threshold could even be acquired through policies pursued by dictators (Glaeser et al., 2004; Djankov et al., 2003).

The last proponents closely relate to the first two and emanates from recent compelling work of Acemoglu and Robinson (2012). It argues specifically that where inclusive political institutions were established, they influenced inclusive economic institutions, that in turn, affected the long-term development and prosperity of the former colonies. Conversely, where extractive political institutions were established, they gave rise to extractive economic institutions, that led to economic failure of the former colonies. On the empirical front, this proposition suggests some kind of causality running from political institutions to economic institutions, yet it has not been empirically tested in the institutions-development literature. ${ }^{8}$ In Acemoglu and Robinson (2012, 2008, 2006)s' view, political institutions such as democracy and other checks on government are the main mechanisms for securing property rights that eventually stimulate investment in human and physical capital, and therefore stimulate economic growth and development.

Despite their wide acceptance in the institutions and development literature, there is a paucity of empirical tests that examine the first two propositions. Only the third claim has received some attention. However, such work has concentrated on developed countries using cross country analyses and a panel of countries. The cross country and panel studies tend to generalize the causal relationship between institutions and economic development across countries (Przeworski, 2004). The problem of such generalization is that by grouping countries that are at different stages of institutional development and economic development, one fails to address country specific effects of institutions on economic development. The method applied in such analysis fail to address the potential biases induced by existence of cross

\footnotetext{
5 The only paper that has attempted to provide evidence from both historical and econometric perspectives, in support of institutional persistence is Acemoglu et al. (2001) using Gurr's historical data on political institutions. La Porta et al. (1998) only attempted to provide such evidence from a historical perspective. However, the paper also investigated the developed countries.

6 Lipset (1959) advanced the hypothesis that became famously known as the Lipset hypothesis.

7 However, Chang (2011) notes that the paper by Acemoglu et al. (2001) is a partial exception in the sense that it recognizes the twoway nature of the relationship at a theoretical level although it goes on to conclude through the use of instrumental variable that empirically test the causality runs from institutions to development.

8 To the best of my knowledge, no other study empirically tests this claim.
} 
country heterogeneity, which, if not accounted for, may lead to inconsistent and misleading conclusions. Brock and Durlauf (2001) note that the assumption of parameter homogeneity in panel estimates that describe the effects of institutions on economic development across countries is not plausible. For instance, it is difficult to justify that a change in the level of civil liberties has the same effect on economic development in the United States as in Uganda. Chang (2011) contends that the relationship between institutions and development is almost certain to differ across countries. He therefore, suggests that 'Time Series evidence may offer better insights than can cross country section studies, which lump every country from Swaziland to Switzerland do'. ${ }^{9}$

It is against this backdrop that this chapter examines three interrelated fundamental propositions that emanate from institutions-development discourse from a Time series perspective for Uganda. The research provides the empirical evidence for a number of claims about Uganda's lack of economic development. The specific set of questions addressed are: (a) Is there evidence of persistence of institutions in Uganda?; (b) Do political institutions cause economic institutions?; and (c) What is the direction of causality between institutions and economic development in Uganda?

Uganda is selected for this study because it is one of the former colonies in Africa where the British colonialists settled and therefore becomes a natural laboratory to test these propositions. If the argument developed by Acemoglu et al. (2001) that where imperial colonialists settled they created inclusive institutions is valid, then Uganda should have been endowed with robust and growth enhancing institutions. Yet Uganda has suffered from lack of development. This is evidenced by its poor socioeconomic performance with real GDP per capita income estimated at \$725, an estimated $50 \%$ of the population living below the poverty line and life expectancy at birth reaching 59.89 years (UNDP, 2019). All these socioeconomic indicators place it among the poor countries with low human development indexes. The country has also experienced recurring social, political, ethnic and economic conflicts over land resources, and grapples with increasing inequality. It also has high corruption levels sustained by an entrenched system of political patronage. Some scholars have argued that Uganda's development problem cannot be divorced from its institutional history as reflected in the quote below:

In many ways, these factors are inherently linked to the colonial inheritance, the disappointing records of economic development cannot be divorced from its historical context. Thus, the impact of the colonial legacy on the path of development that would be embarked upon cannot be neglected'. ${ }^{10}$

This chapter contributes to the institutions-development literature by first testing empirically the assumption that institutions are persistent- 'The Persistence of Institutions Hypothesis'. The result from this test provide an empirical validation of this assumption. They show that both economic institutions (property rights) and political institutions (political rights and civil liberties) in Uganda have persisted from colonial era to the present day. A second contribution to the literature is an assessment of the direction of causality between institutions and economic development for Uganda over the post-independence period (1962-2019). A third contribution to the same literature is a test of the interdependence and causality between institutions, in particular the hypothesis by Acemoglu and Robinson (2012) that political institutions determine economic institutions. This proposition is herein called 'political vs. economic institutions hypothesis'.

\subsection{Persistence of institutions hypothesis}

As highlighted in the introduction, the institutions-development literature claims that institutions persist although they change. The central question that emanates from this claim is why do institutions persist? North and Thomas (1973) in their first attempt to respond to this question, assert that persistence of institutions may be due to path dependence, the transaction costs of changing them, inertia built into culture, and the slow change of beliefs and ideologies. Acemoglu et al. (2001) build on this first intellectual insight and provide three further possible reasons why institutions may persist. First, they argue that this may be due to the sunk cost of establishment of institutions and the transaction costs of enforcement. In this spirit, the setup of institutions (such as private property rights which place restrictions on government power and respect of private property) is usually costly since it requires the formation of a sizeable bureaucracy and sacrifices while the reputation of these institutions is being built. Therefore, once these costs have been born by the previous elites, it may not be beneficial for the current elites to switch from this set of institutions to extractive institutions per se. In contrast, when current elites inherit extractive institutions, they may not want to incur the costs of setting up the institutions that would constrain them, instead they would prefer to exploit the existing institutions for their own gains.

\footnotetext{
See Chang (2011), p. 483.

10 Fahnbulleh (2006), p. 5.
} 
Second and in support of Bates (1981), their persistence may be due to the investment incentives or the lack thereof of the elites that came to power and their size. Accordingly, if the ruling elites are few, each would have a larger share of the resources of the country, hence, the continuity of the extractive institutions. In contrast, if there are investment opportunities for such elites, they would opt for institutions that protect private property. At the same time, if political elites that come to power don't possess comparative advantage in investment activities, then they would be less willing to enforce private property institutions. This point is consistent with the historical evidence from a number of African countries that shows that after these countries attained independence, the ruling political elites who were never involved in productive activities during colonial rule favored extractive institutions (Acemoglu et al., 2001). Third, such persistence may result because the ruling elites have made irreversible investment and would therefore support institutions that protect private property.

The assumption that institutions are persistent is based largely on informal institutions ${ }^{11}$ (North, 2008; North 1990). However, many institutionalists such as Greif (2006) argue that formal institutions persist when they are consistent with and supported by informal norms, and that most durable institutions are norms. Greif (2006) argues that institutions persist when they are internalized that they are self-enforcing. Therefore, the central question is the role of informal institutions vs. formal institutions in the institution persistence debates, and what interaction exists between formal and informal institutions within the persistence institutions literature such that one can infer persistence from legal institutions? First, it must be recalled that social and political actors respond to a mix of formal and informal constraints. Studies suggest that informal institutions such as clientelism, patrimonialism, and ethnic politics- all of which were common place in Uganda and continue to date, at times reinforce formal institutions (Lauth 2000; Taylor 1992).

Helmke and Levitsky (2004) develop a typology of four basic patterns of formal-informal institutions interaction: complementary, accommodating, competing and constitutive. These authors argue that complementary informal institutions coexist with formal institutions such that actors expect that the rules that exist on paper will in fact be enforced. These types of institutions generally fill in the gap left by formal institutions and address the problems or contingencies that are not explicitly dealt with in the formal rules. Accordingly, the accommodating informal institutions are defined as the 'second best' strategy for actors who dislike outcomes generated by the formal rules but are unable to change or openly break these rules. These types of informal institutions at times enhance the stability or sustainability of formal institutions by dampening demands for change.

These authors define competing informal institutions as those that structure actors' incentives in ways that are incompatible with the formal rules: to follow one rule, actors must violate another. Examples of these institutions include clientelism, patrimonialism, clan/ethnic politics and other particularistic institutions (O'Donnell, 1996). In the context of Uganda as argued elsewhere in the study, the formal institutions were reinforced by informal institutions in particular the competing and accommodating institutions. The informal institutions, that is, ethnic politics permitted sustenance of formal institutions that were largely shaped along clientelism and patrimonialism. The abuse of state machinery and widespread vote fraud pursued through formal institutions was backed up by the political players' knowledge that they had majority vote from their ethnic groups. Evidence of this close interaction between formal institutions and informal institutions in Uganda is reflected in a number of events in which heads of Parastatals, the Military, Police and Security apparatus were and are appointed along ethnic lines and then backed up by corresponding legal formal institutions (Widner, 1992). Public goods provision, that is, roads construction is done along ethnic lines yet backed by legal frameworks (Burgress et al., 2013).

Given our argument that formal institutions in Uganda closely tracked behavior of political agents and the interaction between formal and informal institutions in the country. This paper will test empirically if indeed institutions have persisted in Uganda using de-jure formal proxies. It will explore the reasons for such persistence. It aligns theoretically with the framework proposed by North and Thomas (1973) that persistence of institutions is implied in path dependence. Thus, a test of path dependence remains largely a test for persistence of institutions. The concept of path dependence was developed by Arthur (1994) and David (1994, 1985). It refers to situations where the formations of current economic or institutional outcomes are shaped by the path of earlier outcomes and not simply by current conditions. In that sense, history may have a lasting effect on shaping current economic or institutional outcomes. According to Page (2006) path dependence may arise due to: increasing returns to scale, self-enforcement, positive feedback and lock-in effects.

Pierson (2000) further provides rigorous definitions for the concept of path dependence, which enables this study to test the assumption of persistence of our newly constructed institutional variables. Two distinct concepts that relate to

11 The informal institutions in our context are defined as socially shared rules, usually unwritten, that are created, communicated, and enforced outside of officially sanctioned channels (Brinks, 2002; Taylor, 1992). 
the issue of path dependence are of interest: Outcome dependence and equilibrium dependence. First, a dynamic process is outcome dependent if the current outcome $y t$ is determined by past outcomes $y t-s$ where $s=1, . . . . t$. In page's parlance, an outcome dependent process is said to be path dependent when history of outcomes matters but not the sequence or order in which that history occurred. On the other hand, an outcome dependent process is path dependent if the sequence of events in history matters. Secondly, the data generating process (the distribution of function) that transforms past outcomes into current outcomes is equilibrium dependent if the limiting process or distribution does not converge to a unique probability distribution function.

\subsection{Political institutions vs. economic institutions hypothesis}

In their latest book, Acemoglu and Robinson (2012) make the compelling proposition that broad-based/inclusive political institutions are a prerequisite for building the kind of economic institution from which growth can translate into sustainable development. Using historical examples to support their argument on why some countries or nations fail and others succeed, Acemoglu and Robinson (2012) theorize that the political institutions which they claim because economic institutions can be divided into two groups- extractive institutions and inclusive institutions. By extractive institutions, they refer to the type of institutions that are exploitative while the inclusive institutions are those that allow many people to be included in the process of governance and the exploitation process is usually absent. This hypothesis has not been empirically tested as it is fairly recent. This study makes the first attempt to test this proposition in the context of Uganda. It adopts a simplified causality approach in assessing whether there is a causal link coming from political institutions to economic institutions.

\subsection{Empirical discussion of institutional reforms in Uganda}

Uganda has been noted to be a Public Sector reform leader in Africa, and has pursued reforms actively and consistently for over three decades now, and has produced many laws, processes and structures that are 'best in class' in Africa and beyond. It was one of the earliest countries to initiate reforms on the continent in the 1980s and was an early adopter of many interventions that are now ubiquitous on the continent. These include independent revenue agencies, mediumterm expenditure frameworks, public expenditure tracking surveys and results oriented management mechanisms. A number of the solutions introduced in these reforms are respected across the continent because they have yielded bestin-class new laws, organizational arrangements and operational mechanisms. The problem is that many of the reforms have been limited to these gains-producing new institutional forms that function poorly and yielded limited impacts. New anti-corruption laws are largely unimplemented, for instance, which means that corruption continues to be a major problem; impressive looking budgets are poorly executed, which means that public expenditure results are still constrained; the revenue agency collects less than possible, which means that the government lacks resources to independently provide the services and infrastructure needed to develop Uganda; and more.

In 1986 when President Museveni's NRM ascended to power, his government inherited a largely dysfunctional public service. The maladies were too numerous that include specifically: government bureaucracy and red-tape in service delivery; a bloated public service with excessive manpower; low motivation especially of teachers and health workers; no strategic direction for government to follow; the state was in fiscal turmoil, with uncertain spending patterns and large debt burdens; limited revenue to cover debt repayments or to fund needed public sector engagements; and corruption was considered a major problem.

Faced with these challenges, the NRM Government promised Uganda's citizens a fundamental change in the management of public affairs, adopting a ten-point program soon after taking office. This was followed by the adoption of an economic recovery package which sought to liberalize and stabilize the economy in 1987, the establishment of the Public Service Review and Reorganization Commission (PSRRC) in 1988, the adoption of this Commission's report as a blue print for reform in 1989, and the launch of a Civil Service Reform Program (CSRP) in the early 1990s. These steps were among the first and has been constant and busy process reform over the past 30 years.

All these reforms have been active since the early 1990s when Uganda Revenue Authority (URA) was created, a new constitution introduced, pay reforms initiated, the civil service rationalized and streamlined, and budget reforms adopted. It should be noted that many of the reforms attempted during this time have had a cutting edge dimension as well; Uganda was one of the first countries to adopt a semi-autonomous revenue agency in Africa, for instance, and their efforts to introduce medium-term budgeting in the early 1990s predated efforts to do so in other African countries including South Africa, where medium term expenditure frameworks were only introduced in the late 1990s.

The mid to late 1990s saw a variety of initiatives aimed at streamlining the civil service, formalizing the public financial management system, and focusing the public administration. The period laid down the foundation for a series of 
interventions introducing decentralization and emphasizing basic service provision especially universal primary education. The aggressive push for public service delivery was guided by the Poverty Eradication Action Plan (PEAP), which was the first of a number of Plans Uganda government had adopted in the past 20 years. The PEAP saw a push to deliver services by Local Governments, which was a common reform in Africa at the time (Andrews, 2003a). The major decentralization mandate emerged from the 1995 Constitution, the Decentralization Statute No.15 of 1995, and the Local Government Act of 1997.

The government revived the civil service reforms again in the late 1990s as well, with the Public Service Reform Program, a new commitment to pay reform, and efforts to introduce performance management mechanisms. Once again, these efforts were at the vanguard of reforms in Africa, where few countries were seriously considering introducing a results focus in government (Andrews 2005). Uganda's expenditure tracking efforts were also novel at this time, and have since become a 'best practice' across Africa.

The 2000s saw a flurry of new laws passed as part of the continuing public sector reform initiatives. These included laws aimed at further improving the public financial management system. The Budget Act and Public Financial Accountability Act 2003 stood out as impressive legislative interventions and the Public Procurement and Disposal of Public Assets Act remains one of the most advanced procurement laws in the world. A host of new laws and regulations were also introduced to combat corruption. These included the Inspectorate of Government Act, the Leadership Code Act and the Anti-Corruption Act. Various organizational adjustments were made in concert with these laws, leading to the creation of new bodies to provide financial, procurement and other oversight mechanisms in the country. These bodies create and monitor rules of the game, conduct audits, and oversee the implementation of laws.

The key question is where these have and other reform interventions left Uganda today? Unfortunately, Uganda's Government is not as good as it looks. In practice, the reforms in many areas have actually been limited to impressive appearance and not yielded the kind of action and effectiveness needed for a developing country with major problems getting basic services delivered or addressing significant poverty challenges or socioeconomic deficiencies.

Civil service and public administration reform limits began to manifest in the late 1990s, when government employment started expanding even after the cuts. Various policy decisions like decentralization and universal primary education led to hiring pressure in local governments and schools and contributed to a major growth in the number of government employees. Precise data are difficult to come by, given the many different conditions of employment for public servants.

The growth in government size would not be a worry if Uganda had money to finance its public employment in a sustainable and controlled manner and if results of the high employment were tangible in improved scope and quality of service delivery. Unfortunately, the evidence does not support such a positive version of the government expansion story. The government has not dramatically improved its capacity to afford such a large workforce and service results don't appear better as in the past decades. Furthermore, there seems to be little de facto control in the civil service regime, reflected in a festering problem of ghost workers and arrears across government. Audits have found ghost workers in fields such as health, policing and education; and thousands of ghost teachers in Schools. Arrears are also commonplace, again many different areas of government activity. Dating back to the early 2000, one can find civil society reports of such arrears bubbling onto the streets in the form of strikes or rallied by University lecturers, teachers and doctors and other government employees. The official reports don't suggest that arrears are major fiscal problem to the state, but the regularity of salary arrears lasting for two or three months at a time indicates that there are control and management constraints in the civil service system.

These problems persist despite many institutional solutions that were meant to address them including commitment controls mechanisms and IFMS. The new IPPS is also meant to help enhance control, but it is not working effectively as in sometimes it captures wrong salary scale and manipulation of the system by Human Resource and IT professionals in the MDAs.

The limits of past reforms and effective nature of the public administration are further evidenced when looking at performance management and plan implementation in Uganda. Whereas the country was a continental leader in introducing different versions of results-management and government wide planning, it has not proven very effective at producing results or implementing plans. Performance mechanisms, including budgets for organizations and contracts for managers are still not used effectively with budget allocations still not tied to results (Williamson, 2003). Beyond this, national plans have not been consciously implemented and performance is low (RoU, 2012); 56\% of national development plan performance targets are not even assessed; $22 \%$ of the targets that have been assessed have not been achieved; only one of the 16 national core projects has been achieved, and ten (63\%) are off track or there is no assessment.

In short, there seems to be a gap between the civil service and public management systems that exist in form and their functionality or impact. This gap is most evident when considering the expectations citizens have of service delivery 
and execution by government. Data on this is difficult to come by, with the then Afro barometer survey providing the accessible source. According to this source, citizens have very little faith in the government's ability to do key things; $79 \%$ think that government manages the economy very badly or fairly badly; $77 \%$ answer similarly when asked if government handles the problems of poverty well; $82 \%$ think government manages equity issues badly; $51 \%$ and $44 \%$ view government healthcare and education service provision negatively; $54 \%$ feel that government handles water and sanitation very or fairly badly; $67 \%$ and $68 \%$ note that government handles maintenance of national roads and bridges and local roads poorly; $78 \%$ think similarly for electricity supply and more. These data though should be handled with caution show that there is a deficit of trust and expectation on the part of citizens- meaning they don't see the government as effective even after three decades of reforms and the adoption of best practices mechanisms in the civil service and planning realms. The government simply looks better than it is after these reforms, and the gaps need to be closed.

Similar gaps also exist in the area of Public Financial Management (PFM). Whereas reforms have produced a PFM system where laws and processes comply with over $70 \%$ of the good international practices measured in the multi-donor PEFA assessment, actual implementation complies only 50\% with these practices. This means that Uganda has many areas in its PFM system where laws and practices are not being properly used or implemented. The PEFA scores are high (A or B) when asking if a budget calendar exists but the scores are low (D) when assessing if the budget preparation has actually been completed in the calendar period. The gap between the de jure form and de facto functionality is quite significant and can be found throughout the PFM system. Various authors have written about it over the years as well, providing further evidence of its existence and importance. In 2003, for instance, Williamson identified that whereas government had invested in adopting an output/outcome budgeting system, and Sectors are required to analyze past performance of outputs and outcomes and to set future outputs and outcome targets to be achieved over the MTEF period, the Ministry of Finance has tended to continue with incremental budgeting and not allocate funds on the basis of performance.

Another gap exists between the quality of upstream budget preparation mechanisms and downstream budget execution mechanisms. This is reflected in PEFA scores where budget preparation mechanisms score an average of 2.8 of 4 but execution mechanisms score 2.1 and in the OBI. The OBI data shows that Uganda has significant transparency in the way it produces its budgets and communicates what it plans to spend (scoring $73 \%$ on the questions about transparency in budget preparation. However, it only satisfies $48 \%$ of the requirements associated with transparency of budget execution (where the focus is on transparency of what was spent and what results ensued. This means that reforms have provided an effective window onto the promises of government but leave it very difficult to see the actual activities and impact of government. It also means that PFM systems are not providing the kind of information during implementation that government needs to ensure that spending is effective and efficient, and that goals are being met, and that lessons are being learned about how to properly execute complex public sector spending plans. The continued weakness of these implementation systems-even after decades of reform-manifests in the regular deviation of actual spending from budgets (this deviation exceeds 10\%) and is a major reason why service delivery remains deficient and why the country continually struggles to find domestic fiscal space for important spending (like infrastructure spending).

The gap between appearance and reality is apparent in the area of revenue administration as well. Whereas the country has a revenue agency that satisfies many good practice organizational criteria, for instance, it is also considered very corrupt. The 2018 Afro barometer survey found that $69 \%$ of respondents had little to almost not at all trust in URA and $90 \%$ felt that some, most or all URA officials and other tax collectors were corrupt. This perspective has been reflected in various studies and surveys over the past 15 years with a 2017 Transparency International Study showing URA as the 'most corrupt tax institution in East Africa. The URA performed similarly poorly in the 2016 East African Bribery Index, which portrayed it as the most corrupt public entity in Uganda.

Beyond this, the URA has not been very effective as a revenue collection agency. Collections stagnated after 1999 and have been in a band between 11 and 13\% of GDP in very year except 2011 when there was growth because of oneoff deals and early impact of oil revenues (AfDB, 2010; Ronald, 2011). The percentage is low compared with other African countries-where average tax to GDPratio exceeds 20\% in East Africa and beyond (Drummond et al., 2012; Ronald 2011). The problem of low government revenue means that Uganda is heavily dependent on external financing (with about $25 \%$ of its budget funded by outside agencies). The country has a perpetual financing gap that limits infrastructure and other expenditure (which is lower than other African countries).

Various observers argue that the problems in the URA (with corruption and weak tax collection) fester because tax reforms have not addressed key constraints. These include a continued reliance on informal markets, low tax morale, low trust in government and resulting failures to pay tax, low political support for revenue reforms, and bureaucratic and political influence of the URA (Kidd and Crandall, 2006). In respect of the last issue, observers note that the semi- 
autonomous URA is anything but, and is rather prone to close oversight and patronage by the national political leadership (AfDB, 2010). There is further perception that tax incentives and exemptions have been imposed on the URA by political leaders-even though the URA's semi-autonomous status should limit such influence. While many perspectives on this issue are possible, it seems fair to conclude that Uganda's revenue reforms have not yielded the results that were needed- there have been limits in reform and gaps exist between what the reforms delivered on paper and how they function in practice. Ronald (2011) wrote as much as in 2011, observing the continued poor domestic revenue mobilization despite many tax reforms established since the 1990s.

The area of procurement offers similar evidence. For instance, Cornelia Sabiti from PPDA noted that the new processes introduced since 2002 are not being implemented. Compliance was around $40 \%$ for contract award and record keeping only at $40 \%$ according to the mandated processes. The PPDA targeted $100 \%$ compliance with complete record keeping requirements but in $2017 / 2018$ only $17.1 \%$ of the contracts complied with this. The assessment also found that the average time taken for all kinds of bids was much longer than the government set targets. The target for open international bidding is 155 days but the average performance is 341 days, while the target for open domestic bidding is 132 days yet what had been registered is 334 days.

Beyond this, PPDA Procurement Integrity Survey reports that suppliers spend up to $20 \%$ of contract amounts on corrupt payments, up from $10 \%, 10$ years ago in 2008. This amounts to about $\$ 240 \mathrm{mn}$ in bribes. Such problems exist despite the many best practice reforms introduced in Uganda. This is reflected in comments from Anja Kramer of KfW and Howard Centenary (World Bank, 2004) who note that various new mechanisms are not working well. It is also noted that procurement laws are not being implemented in local governments (Shipman 2007; Basheka 2008). The survey by these two authors reveal that fundamental challenges were not dealt with, including lack of functional and effective procurement and disposal units created in name but with no appointments and problems in carrying out market surveys and ensuring local markets could facilitate the kinds of procurement being planned and collusion in bid preparation among district staff. These kinds of constraints are reflected in the weak scores Uganda gets on OECD procurement assessments of capacity, operations and transparency in the system. This shows that Uganda scores much lower on questions about practice than it does on questions asking about legal reforms.

The situation is similar when looking at anti-corruption reforms. Global Integrity gives Uganda 98 out of 100 on the quality of anti-corruption laws. The country is in full compliance with $95 \%$ of the questions about the quality of laws. But it scores only $51 \%$ of 100 when the Global Integrity survey asks about implementation of laws, with full compliance only $11 \%$ of the questions about implementation and practice. Uganda is noted to have the best anti-corruption laws but has one of the poorest records of implementing such. This is a problem with real implications for Uganda. Costly corruption crises are common place, and corruption is considered pervasive. Some of the scandals of corruption are $\$ 10 \mathrm{mn}$ of Global Funds was misappropriated in 2006, leading to constraints in the supply of malaria and TB drugs, the country also lost significant funding from donors because of this risk. The bicycle scandal of 2011 saw payments for 70000 bicycles made without any bicycle being delivered. UGX 60 billion went missing from the Microfinance Support Center in a period of three months in 2011. The pension scandal of 2012 involved the loss of UGX 169 billion meant to finance outstanding pension claims. In 2012 UGX 5 billion in donor funds intended to fund Peace Recovery and Development Plan for Northern Uganda went missing causing a variety of donors to freeze development aid.

The variety of areas in which crisis has occurred shows how widespread corruption still is in Uganda. Transparency International's Corruption Index provides further evidence of this. The score of 26 in 2019 out of 100 showing that level of corruption is high. There has been significant acceleration in corruption as well and the country now sits at 149 of the 179 countries in 2019. Reflecting on such situation, the think tank Global Integrity describes Uganda as a place where there has been tough talk, much noise but no improvement. This trend indicates that the perceived level of corruption has hardly, if at all, improved during the last decade despite numerous and highly publicized attempts at reform.

Reforms have had limited success partly because they didn't deal with the contextual realities of corruption in Uganda. Ittner (2009) argues that the main enforcement body is the Uganda Police Force, which is widely considered one of the most corrupt entities in Uganda. He outlines various reasons why Police corruption festers, including low pay levels, poor leadership, corruption at the top of the Police Force, political influence over key appointments, and more. He notes that government has adopted reforms designed to address these challenges in the Police Force, but with limited success, because these reforms were themselves not properly implemented. In 1996, for instance, the National Fraud Squad was created to investigate government and parastatal corruption cases. But it suffers from lack of equipment and has only limited capacities and little incentives for accountable and transparent working practices (Langseth and Pezzullo, 2000; Flanary and Watt, 1999). Ittner (2009:86) argues that, the current consensus is that the squad remains 
largely ineffective due to constraints and is unlikely to have any impact on the level of corruption which should make it clear that Uganda's corruption problem will not be solved by creating new laws for the flawed police to or not enforce.

\subsection{Why do countries such as Uganda fail to develop market-supportive institutions?}

It should be noted that most of the world has not been able to replicate the beliefs and institutions that characterize developed, open access societies. Many underdeveloped countries such as Uganda don't even pretend to open access rules. Most of these countries have installed the same rules as open access societies; they have competitive elections, market economies, diverse civil societies, religious tolerance, active universities, a free press, and the like. Yet these rules don't function in the same way as they do in richer open access economies. Although access is nominally open to all, non-elites face large transaction costs and informal barriers to starting a new business, getting credit, or finding a job in the formal economy. They also face high costs and barriers to creating political or civil organization, getting response from their political representatives or negotiating with the bureaucracy.

There are large volumes of literature reviewed which purport to explain why most countries failed to develop marketsupportive institutions and beliefs that were so important to European development. These have been explained along four main categories: colonial heritage; factor endowments plus colonial heritage; conflicts and beliefs and norms; as well as the natural state. Hence, although enough effort has been made in this study in understanding the high quality institutions that lead to development, our understanding of what led to underdeveloped institutions is less advanced, and we still have very partial knowledge of how institutions change. Institutions are persistent, but they are also endogenous. The challenge ahead is to move our understanding of institutions beyond the present abstractions and provide findings that are more useful for decision-makers and citizens of poor countries. Measuring institutions turn out to be far more difficult than it sounds. Economists have put considerable effort into defining and testing institutional variables for cross-country growth regressions, but far less effort has gone into measuring institutions in specific countries. Specificity is crucial because the same institutions work very differently in limited access and open access societies. Because they lack specificity, few current institutional measures are 'actionable', that is, able to help researchers analyze the causal effects of specific institutions, help citizens to demand better institutions and hold leaders accountable, help reformers design successful and sustainable improvements in institutions, and help aid-givers judge when countries are able to use aid more effectively.

\subsection{Measurement of institutions}

Institutions are correlated with growth. If institutions matter for growth then democracy and long-run growth should matter, since democracy represents a prime set of institutions. Yet it has proved impossible to find a clear relationship between democracy and long-run growth, probably because we cannot measure institutions adequately. Despite such weaknesses, institutional indicators are widely used by aid agencies. The measurement of institutions is still in its infancy. The current measures are not actionable. They are too crude to help concerned citizens design reforms and gauge their outcomes. The current set of measures may be seriously misleading about micro-developments. Part of the fault for the weakness of the measures lies with researchers who have focused their attention and efforts on variables that can be used for cross country regressions.

Developing more useful measures of institutions will not be simple. Ultimately, consistent, comparative studies will be crucial if we are to understand the complex nature of institutions and institutional change and develop more specific and accurate measures. It would be helpful to analyze the CPIA rankings retrospectively to see how accurately they predicted relative performance.

Change in deeply-rooted institutions and beliefs begin with a series of policy reforms and supported by a new set of assumptions about the way the economy functions- a new economic paradigm. The process of changing the economic paradigm begins with a felt need for reform among those powerful enough to enact new policies and to change institutions. Their desire for change may be triggered by an external threat such as foreign competition for trade or military dominance, or even by economic upheavals such as hyperinflation or abrupt economic decline, problems that are not remedied by status quo policies and institutions. This situation creates the potential for radical change in economic paradigms even though elite actors may only be seeking to change policies in the first instance.

Hence, meaningful change is only feasible, when those with power to effect change are in a position to ignore, overpower, or buy out those who oppose them. Such an opportunity could arise because the usual power relationships have been undermined by crisis, or weakened or overturned through political change such as a revolution, coup or election. The elite must accept the new policy program and its corresponding rationale and its paradigm. This new paradigm must be seen as relevant to the perceived problem, different from the previous failed models, and internally coherent. 
I can summarize the above discussions of the respective chapters as follows:

i) Change is seen as necessary: those who have the power to make radical changes(a) face serious threats or economic shocks, and (b) perceive that previous reforms failed to solve these problems;

ii) There is a viable alternative: an alternative economic vision exists that is internally coherent and different from previous failures;

iii) There is a role model: the alternative vision is supported by a role model, that is, some applicable experience elsewhere;

iv) The alternative is the consensus of a group of experts: the alternative vision is the consensus proposal of a group perceived as experts by those who have the power to make radical changes and seen as trust-worthy because the proponents are believed to be disinterested; motivated to be truthful; and knowledgeable;

v) The alternative is feasible: those in position to effect change have the prestige to co-opt, compensate, or coerce interest groups who might oppose radical changes;

vi) The alternative is known by the elites: the expert group has channels to make their alternative vision known to those with power to effect change;

vii) The alternative is diffused: expert proponents and political leaders have the prestige, persuasive power, and media access to diffuse the new vision to those interest groups whose beliefs need to change for the new institutions to become self-enforcing;

viii) Early outcomes are successful and create beneficiaries who support further change: early attempts to enact the new policies and institutions proposed by experts are successful in eliminating or reducing the economic problem and create beneficiaries who organize to prevent retreat and to promote further change.

\section{Conclusion}

This section has provided the application of theoretical assumption that institutions are persistent. The results from these assessments show that institutions are time variant: the property that implies institutions are indeed path dependent or persistent. The results validate this commonly held theoretical assumption when discussing about institutions. The causality between different types of institutions- political institutions and economic institutions were also discussed. The results show the presence of long run causality between political institutions and economic institutions as reflected in the reform agenda of public sector institutional reforms in Uganda. This lends support to the hypothesis by Acemoglu and Robinson (2012) that political institutions cause economic institutions, which in turn cause long term growth and development.

The results have strong implications for the analysis of the relationship between economic institutions and political institutions, and on whether countries that reform their economic institutions first are more likely to experience economic growth dividends than those that reform their political institutions first. The results presented in this chapter show the possibility that the reverse causality could hold hence the economic literature and institutional reformists need to be cautious and consider all different possible associations before recommending any policy reform. On the basis of these results from this chapter, the dissertation argues that the poor economic development path of Uganda is a result of the continuation of colonial structures in the post-colonial state by the ruling elites.

There is little evidence to suggest that Uganda's institutions are conducive to achieving structural transformation, particularly in terms of fostering the types of state capacity required to achieve this. Research on developmental states suggests that in addition to maintaining political and macroeconomic stability, this also requires both synergistic relationships with productive capitalists (Evans, 1995) and the capacity to discipline capital in line with the national interests (Khan, 2005); the capacity to restructure property rights for growth, for example, prioritize the allocation of public land, carrying out pro-poor land reform; and to assist in technology acquisition through prioritized infrastructure support (Gore, 2000; Khan, 2005).

The researcher's analyses suggest that Uganda largely lacks other capacities identified here, and that even here there are question marks. The case of macroeconomic stability is particularly revealing of the interplay between the political actors, ideas and transnational actors in Uganda overtime, and how this shapes capacity and commitment to deliver. The very creation of the Central Bank of Uganda in 1966 coincided with the onset of constitutional crisis and eventual armed conflict between the regime and forces loyal to the Baganda monarchy, setting in play what Mazrui (1991) referred to as 'The dialectic between militarized politics and structural adjustment through fiscal adjustment'. Efforts by the first Governor to secure fiscal sovereignty for the Bank were ultimately in vain, with Amin allegedly 
ordering his murder(op.cit). The establishment of a more positive synergy between fiscal and military discipline would have to wait until Museveni finally invested the Bank with autonomy and supportive macro-economic policies in the early 1990s (Tumusiime-Mutebile, 2010). Indeed, it is suggested that Museveni only bought into the idea of maintaining macroeconomic stability vis-à-vis a mixture of ambitious expenditure plans and public sector profligacy when he came to understand economic governance in terms of military discipline (op. cit.). This commitment was heavily influenced by the need to retain good relations with the IFIs during the lengthy period through which Uganda was both heavily indebted and aid dependent. As reported by Mosley (2012), President Museveni was persuaded by the Governor of the Bank of Uganda to effectively hand over the reins of economic governance to him, thus enabling the Governor to take a lead role in handling donors and building up a cadre of highly competent public servants securing in the key economic institutions. In many ways, the Governor personified the 'embedded autonomy' (Evans, 1995) required for states to perform developmental functions, in that he maintained close relations with the executive while keeping key economic institutions largely free from external political pressure. Given its strategic importance, the regime remained happy to allow, if not actively promote economic governance institutions to function as 'islands of effectiveness', particularly within MFPED and BoU, in ways that were not apparent in other areas of public service.

The question now is whether this commitment remains, now that both the political and political economy of development has changed in Uganda. Relevant shifts include the return to multi-party politics, the declining dependence on aid and additional resources generated through new found oil and growing investment from new economic partners, especially China, and new geopolitical imperatives resulting from Uganda's involvement in Somalia and security concerns over South Sudan. For example, the deepening of competitive tendencies within the Ugandan polity following the return to multi-party politics in 2005, and the decision by Museveni to commercialize/buy rather than enforce victory at the 2011 elections (Izama, 2011), seems to have led the regime to become more relaxed about macroeconomic stability, which was compromised by the very high rates of public expenditure over 2010-12. Although economic factors are important here, the problems of high inflation and limited growth seem to have been driven in part by the lack of fiscal discipline around the 2011 elections, particularly in terms of the use of supplementary budgets to cover high levels of unscheduled expenditure on campaign costs and military hardware (Izama, 2011), the latter being justified with reference to regional security concerns. In the context of increased electoral pressures, 'competitive clientelism' requires an increasingly expensive patronage machine to maintain the regime in power (Barkan, 2011). This raises concerns that the regime will be increasingly willing to compromise on short/medium term macroeconomic stability targets, and that the 2021 elections saw Uganda increasingly resemble countries like Ghana, where Those associated with high-performing institutions of economic governance have expressed concern: for example, the IMF initially refused to award Uganda its stamp of approval in 2011-12 concerning the Policy Support Instrument, and the World Bank Uganda's Senior Economist stated publicly that the 'continued use of supplementary budgets is affecting budget credibility and started to raise questions about the degree of fiscal control by the authorities.' The Governor Bank of Uganda gave an interview to the UK-based Financial Times during the summer of 2011 bemoaning the level of political interference in the economy. Initially, the mini-economic crisis enabled the Bank of Uganda to re-assert its technocratic credentials, as it imposed strict monetary tightening measures over 2011-12, most notably through high interest rates, which proved successful in terms of reducing inflation to within single digits from a high of $30 \%$ in 2011, albeit with costs in terms of growth and productivity. However, the fact that the President's support was required in March 2012 to ensure the Governor escaped censure in Parliament for his role in a political corruption scandal suggests that the autonomy of this pillar of economic governance may have been further compromised. Macroeconomic discipline tends to be cast aside during elections. ${ }^{12}$

In terms of restructuring property rights for growth, the government has generally failed to ensure that one of Uganda's most significant assets, namely its highly productive and fertile land, is distributed in ways that maximize returns on investments. This failure to persist with and implement land reforms reflects in part the nature of the ruling

12 Those associated with high-performing institutions of economic governance have expressed concern: for example, the IMF initially refused to award Uganda its stamp of approval in 2011-12 concerning the Policy Support Instrument, and the World Bank Uganda's Senior Economist stated publicly that the 'continued use of supplementary budgets is affecting budget credibility and started to raise questions about the degree of fiscal control by the authorities.' The Governor Bank of Uganda gave an interview to the UK-based Financial Times during the summer of 2011 bemoaning the level of political interference in the economy. Initially, the minieconomic crisis enabled the Bank of Uganda to re-assert its technocratic credentials, as it imposed strict monetary tightening measures over 2011-12, most notably through high interest rates, which proved successful in terms of reducing inflation to within single digits from a high of $30 \%$ in 2011, albeit with costs in terms of growth and productivity. However, the fact that the President's support was required in March 2012 to ensure the Governor escaped censure in Parliament for his role in a political corruption scandal suggests that the autonomy of this pillar of economic governance may have been further compromised. 
government and in particular the fractious relationship between the regime and the Baganda. More broadly, when the President has sought to intervene directly, as when trying to appropriate land for larger capitalists to develop, for instance Sugar plantations in the north, he has often been unable or unwilling to face down the groundswell of local protest against such moves, indicating that current political institutional set up or social contract between the state and society in Uganda, as elsewhere in Africa (Nugent, 2010), does not yet stretch to allowing the state to restructure power relations around land. This reflects a broader problem whereby most Ugandans don't perceive that the regime's efforts to reform land tenure systems or implement other legislations around land is being undertaken in the national interest, rather than his own or that of elites around him. As suggested by some thinking on state capacity (vom Hau, 2012), legitimacy is a key mediating factor, which can either enable or disable government action.

Importantly, the agricultural modernization required to push forward structural transformation in Uganda is highly unlikely to occur, given both the meager size of the budget allocation for this area(which at around $4 \%$ of the budget and is less than half of that recommended by the Maputo Agreement), the high degree of politicization of policy making and delivery in this area (Kjaer and Muhumuza, 2009) and state's related lack of institutional capacity to deliver integrated and effective forms of agricultural policy. The policy responses on employment generation to date have been piecemeal, focused on training and low-level incentives, rather than more strategic interventions.

The capacity of governments in Africa to not only 'pick winners' but also, and more importantly, discipline losers, is a key difference between limited development progress that the continent has experienced in comparison to East Asia. Uganda reflects this general scenario, as evidenced in Museveni's periodic efforts to identify winners, from the Strategic Exports Initiatives of the early 2000s (Hickey, 2005), through to these efforts to secure land for particular companies to establish sugar plantations. As an IMF report notes, 'In recent years, tax breaks and/or government financial support have been provided to activities as varied as the hotel and tourism sector, hides and skins, textiles, palm oil production, microfinance and so on (Selassie, 2008, p. 37), few with any lasting success and nearly always accompanied by suspicions that the benefits have been mainly garnered by NRM loyalists.

As such, the government of Uganda clearly lacks the capacities usually associated with achieving the ambitious goal of structural transformation. A further bottleneck concerns the limited institutional power and intellectual capabilities that lie behind the structural transformation agenda in Uganda, whereby the 'new productivists' (Hickey, 2012b) currently lack the political weight and analytical capacities to make and win intellectual and strategic case for higher investments. In general, though, it will not be easy to overcome the capacity gaps identified here, Uganda's ideological shift to a largely market-oriented approach in the late 1980s and 1990s involved privatizing most public utilities and reducing the government's role in the economy. Having failed to adopt the developmental state structures associated with fasttransforming states, building them now will require a degree of effort and discipline that is at odds with the country's trajectory regarding the incentives that prevail within the political establishments or institution.

In conclusion, institutions in Uganda contain few incentives for political elites to ensure that effective, impersonal and accountable institutions emerge and are allowed to function. This has the effect of reducing the capacity and commitment of the state to deliver development and structural transformation. Prime examples include accelerated districtization, an apparent erosion of the few pockets of bureaucratic excellence in public service terms, a flattening taxtake and a poor and worsening record on delivering public goods and implementation across the board. There is also something of a vicious cycle at work here, whereby the relatively slow rate of structural transformation stymies the creation of more autonomous economic interest groups and urbanization, which is linked to catalyzing processes associated with improved levels of democracy and governance (Khan, 2005, 2010).

The return of multi-party politics has further politicized public policy making and has both deepened and broadened the level, and the costs, of patronage, thus reducing the availability of resources for productive investments. However, the deepening of electoral incentives heralded by the return of multi-party politics has also meant that, to some extent and in some areas at least, the terms of inclusion within the current ruling regime are being re-negotiated and in ways that appear to be deepening elite commitment towards inclusive development. Also, and as predicted by Levy (2012), even within such clientelistic settlements there remains at least some room for maneuver in certain policy spaces, particularly those involving existing pockets of bureaucratic excellence. Some bureaucrats in key positions remain committed to ensuring that evidence-based development policies are made and delivered, and there is some room in the realm of ideas and strategic thinking for external brokers to engage.

Uganda therefore, has moved from a situation where politics seemed to be broadly aligned with agenda of inclusive development, to one where most observers are convinced that its developmental orientation is in decline; and experiencing a deepening of tendencies associated with competitive clientelism, although still with a dominant leader in charge within 
which the President remains the hegemonic centrifugal force. This raises interesting typological issues concerning the internal differentiation of the main types identified by Levy (2012), and offers the possibility of identifying how dynamic change within Political and Economic Institutions re-shape the capacity and commitment of governments to deliver inclusive development. This in turn can provide grounds for developing new hypothesis for future research provide grounds for developing new hypothesis for future research.

\section{References}

Acemoglu, D. (2003). The form of property rights: oligarchic vs. democratic. National Bureau of Economic Research (NBER), Cambridge, MA, Working Paper, No.10037.

Acemoglu, D. and Robinson, J.A. (2008). Persistence of Power, Elites, and Institutions. American Economic Review. 98(1), 267-293.

Acemoglu, D. and Robinson, J.A. (2012). Why Nations Fail: The Origins of power, prosperity, and poverty. Crown Publishers, New York.

Acemoglu, D., and Johnson, S. (2003). Unbundling Institutions. NBER Working Papers 9934. Nation

Acemoglu, D., and Johnson, S. (2005). Unbundling Institutions. Journal of Political Economy. 113(5), 949-995.

Acemoglu, D., Egorov, G., and Sonin, K. (2010). Political Selection and Persistence of Bad Governments. The Quarterly Journal of Economics. 125. 1511-1575.

Acemoglu, D., Johnson, S. and Robinson, J. (2005). Institutions as fundamental cause of long run growth. in Aghion and S.N. Durlauf (Eds). Handbook of Economic Growth. 1a, 385-472, Elsevier, Amsterdam.

Acemoglu, D., Johnson, S. and Robinson, S. (2001). The colonial origins of comparative development: an empirical investigation. Economic Review. 91(5), 1369-1401.

Acemoglua, D., Johnson, S., Robinson, J. and Yunyong, T. (2003). Institutional causes, macroeconomic symptoms:volatility, crises and growth. Journal of Monetary Economics. 50, 49-123

Adam, S. (1776). An inquiry into the nature and causes of the wealth of nations. W. Stratham and T. Cadell, London.

AfDB (African Development Bank) (2010). Domestic resource mobilization for poverty reduction in East Africa: Uganda case study. Regional Development East A(OREA) Paper. November.

AfDB (African Development Bank) and GFI (Global Financial Integrity) (2013). Illicit Financial Flows and the Problem of Net Resource Transfers from Africa: 1980-2009 (Tunis: AfDB).

Aghion, P. and Howitt, P. (1992). A model of growth through creative destruction', Econometrica. 60, 323-351.

Andrews, M. (2003a). Assessing local government performance in developing countries' in A. Shah(ed), Measuring Government Performance in the Delivery of Public Services, Washington, D.C: World Bank.

Andrews, M. (2005). Performance based budgeting reform, in A. Shah (ed.), Fiscal Management, Public Sector Governance and Accountability Series. Washington DC: World Bank.

Arellano, M., and Bond, S. (1991). Some tests of specification for panel data: Monte Carlo evidence and an application to employment equations. Review of Economic Studies 58: 277-297.

Aron, J. (2000). Growth and Institutions: A Review of the Evidence. World Bank Research Observer. 15, 99-135.

Bardhan, Pranab. (2001). Distributive Conflicts, Collective Action, and Institutional Economics. Frontiers of Development Economics.

Barre, Robert, J. (1991). Economic Growth in a Cross Section of Countries. Quarterly Journal of Economics. 106(2), 407433.

Barre, Robert, J. (1996). Democracy and growth. Journal of Economic Growth. 1, 1-27.

Barro, R.J. (1990). 'Government spending in a simple model of endogenous growth. Journal of Political Economy. 98(55), 103-125.

Basheka, B.C. (2008). Procurement planning and accountability of local government procurement systems in developing countries: evidence from Uganda. Journal of Public Procurement, 8(3): 379-406.

Blankenburg, S. and M. Khan (2012). Governance and Illicit Flows' in Reuter, P. (ed.) Draining development? Controlling flows of illicit funds from developing countries (Washington, D.C.: World Bank), pp. 21-68. 
Blankenburg, Stephanie and Khan, Mushtaq (2012). 'Governance and Illicit Flows.' In: Reuter, Peter, (ed.), Draining Development? Controlling Flows of Illicit Funds from Developing Countries. Washington: The World Bank. 21-68.

Cass, D. (1965). Optimum growth in an aggregate model of capital accumulation. Review of Economic Studies. 32 , 233-240.

Coase, R.H. (1937). The Nature of the Firm. Economica. 4(16), 386-405.

Coase, R.H. (1992). The Institutional Structure of Production. University of Chicago Law Occasional Paper, No. 28.

David Dollar and Aart Kraay (2002), Growth is Good for the Poor. Journal of Economic Growth. 7, 195-225

Davis, L. and Hopkins, M. (2006). The Institutional Foundation of Inequality and Growth. 29th June, 2015.

Demsetz. (1967). Toward a theory of property rights. American Economic Review. 57, 347-359.

Docquier, F. (2014). Identifying the effect of institutions on economic growth', in H. Schmiegelow and M (eds). Institutional Competition between Common Law and Civil Law: Theory and Practice. Springer, de Louvain.

Drummond, P.W. et al. (2012). Mobilizing revenue in sub-saharan africa: empirical norms and key determinants. IMF Working Paper WP/12/108. Washington DC: IMF

Easterly, W. (2008). Design and reform of institutions in ldcs and transition economic institutions: top down or bottom up? American Economic Review: Papers and Proceedings. 98(2), 95-99.

Easterly, William and Levine, Ross, (2003). Tropics, germs, and crops: how endowments influence economic development. Journal of Monetary Economics. Elsevier, 50(1), 3-39.

Easterly, William; Levine, Ross. (2001). It's Not Factor Accumulation : Stylized Facts and Growth Models. Washington, DC: World Bank. (C) World Bank. https://openknowledge.worldbank.org/handle/10986/17440 License: CC BY-NCND 3.0 IGO.

Ferrini, L. (2012). The importance of economic institutions to economic development, 30th July, 2014.

Flanary, R., and D. Watt (1999). The state of corruption: A case study of Uganda. Third Quarterly, 2013, 20 (3), 515.

Fosu, Augustin. (2009). Inequality and the Impact of Growth on Poverty: Comparative Evidence for Sub-Saharan Africa. The Journal of Development Studies. 45, 726-745.

Gérard, Tchouassi. (2014). Private Capital and Investment Climate for Economic Growth: Empirical Lessons based on ARDL bound test technique. European Journal of Sustainable Development. 3. 17-32. 10.14207/ejsd.2014.v3n2p17.

Glaeser, Edward, la porta, Rafael, Lopez-de-Silanes, Florencio, Shleifer, Andrei. (2004). Do Institutions Cause Growth?. Journal of Economic Growth. 9. 10.2139/ssrn.556370.

Global Integrity (2007). Global Integrity Assessment.

Grossman, G.M. and Helpman, E. (1991). Innovation and growth in the global economy. MIT Press, Cambridge, MA.

Hart, Oliver, and John Moore. (1990). Property rights and the nature of the firm. Journal of Political Economy. 98(6): 1119-1158.

Ittner, S (2009). Fighting corruption in africa-a comprehensive study of Uganda and Botswana. PhD Dissertation. Speyer University.

Kaufmann, Daniel and Kraay, Aart (2002). Growth without governance, Policy Research Working Paper Series 2928. The World Bank.

Keefer, P. (2005). From settler minority to patrimonialism: weaving the dynamics of political competition into political economy of development. The Political Economy 12, 1345-1358.

Kenneth L. Sokoloff and Stanley L. Engerman. (2000). Institutions, Factor Endowments, and Paths of Development in the New World. Journal of Economic Perspectives. 14(3). 217-232.

Klomp, J. \& De Haan, J., (2009). Political institutions and economic volatility', European Journal of Political Economy. 25,311-326.

Knight, J. (1992). Institutions and Social Conflict. Cambridge, NY: Cambridge University Press. http://dx.doi.org/10.1017/ CBO9780511528170 
Koopmans, T.C. (1965). On the concept of optimal economic growth'. Potificiae Academiae Scientiarum Scripta Varia. $18,115-300$

Lehne, J., Mo, J. and Plekhanov, A. (2014). What Determines the Quality of Economic Institutions? Cross-Country Evidence. SSRN Electronic Journal. 10.2139/ssrn.3121122.

Leonce Ndikumana and James Boyce (2011). Capital flight from sub-Saharan Africa: linkages with external borrowing and policy options. International Review of Applied Economics. 25(2), 149-170.

Leonce Ndikumana and James Boyce (2011). Capital flight from sub-Saharan Africa: linkages with external borrowing and policy options. International Review of Applied Economics. 25(2), 149-170.

Lucas, R.R., (1988). On the mechanism of economic development'. Journal of Monetary Economics. 22(1), 3-42.

North, D.C. (1990). Institutions, institutional change, and economic performance, Cambridge University Press, Cambridge.

North, D.C. (1991). Institutions, institutional change and economic performance, Cambridge University Press, Cambridge.

North, D.C. (1993). Institutions, Transaction Costs and Productivity in the Long Run. Economic History, University Library of Munich, Germany.

North, D.C. (1993). Institutions, Transaction Costs and Productivity in the Long Run. Economic History, University Library of Munich, Germany.

North, D.C. and Thomas, R. (1973). The rise of the western world: a new economic history, Cambridge University Press, Cambridge.

North, D.C., (1988). Some fundamental puzzles in economic history/ development', in W.B. Arthur, S.N. Durlauf \& D.A. Lane (eds.), The Economy as an Evolving Complex System II, pp.223-237, Addison-Wiley, New York.

North, Douglass and Wallis, John and Weingast, Barry. (2009). Violence and the Rise of Open-Access Orders. Journal of Democracy. 20. 55-68. 10.1353/jod.0.0060.

Nugent, P. (2010). States and social contracts in Africa. New Left Review, 63, 35-68.

Okoh, S.A. and Ebi, B.O. (2013). Infrastructural investment, institutional quality and economic growth in Nigeria: An interactive approach. European Journal of Humanities and Social Sciences. 26(1), 1343-1358.

Oliver E. Williamson (2000). The New Institutional Economics: Taking Stock, Looking Ahead. Journal of Economic Literature. American Economic Association. 38(3), 595-613.

Paul Pierson (2000). Increasing Returns, Path Dependence, and the Study of Politics. The American Political Science Review. 94(2), 251-267.

Paul Romer (1986). Increasing Returns and Long-run Growth. Journal of Political Economy, 94(5), 1002-1037.

Paul Romer (1990). Endogenous Technological Change. Journal of Political Economy. 98(5), S71-102.

Pereira, C. and Teles, V.K. (2009). Political institutions are substitute to democracy: a political economy analysis of economic growth', Escola de Economia de Sao Paulo, Testos para Discussoa 196.

Petrunya, U. and Ivashina, A. (2010). Institutional factors of economic development'. Economic Theory. 4, $24-31$.

Polterovich, V. (2008). Strategies of Modernization, Institutions and Coalitions. VOPROSY ECONOMIKI. 4. 10.32609/ 0042-8736-2008-4-4-24.

Przeworski, L. and Curvale, C. (2007). Political institutions and economic development in Americas: The long run, Working Paper, No.13, Institute of Economic Growth, New Delhi.

Reuter, P. (ed.) (2012). Draining development? Controlling flows of illicit funds from developing countries (Washington: World Bank).

Robert E. Hall and Charles I. Jones, (1999). "Why do Some Countries Produce So Much More Output Per Worker than Others?," The Quarterly Journal of Economics, Oxford University Press, 114(1), 83-116.

Robinson, J.A., and Acemoglu, D. (2006). Economic Origins of Dictatorship and Democracy. Cambridge, UK: Cambridge University Press.

Rodrick, D., Subramanian, A. and Trebbi, F. (2002). Institutions rule: The primacy of institutions over geography and integration in economic growth, Working Paper No.wp/02/189, International Monetary Fund (IMF), Washington, DC. 
Ronald, A(2011). Tax reforms and domestic revenue mobilization in Uganda revenue authority: a case study of Uganda revenue authority Entebbe. Research Report for Bachelor of Commerce Degree. Makerere University, Kampala.

Selassie, A.A. (2008). Beyond macroeconomic stability: the quest for industrialization in Uganda. Washington, DC: International Monetary Fund.

Solow, R.M. (1956). A contribution to the theory of economic growth', Quarterly Journal of Economics. (70), 65-94.

Stephen Knack and Philip Keefer (1995). Institutions And Economic Performance: CrossCountry Tests Using Alternative Institutional Measures. Economics and Politics. Wiley Blackwell, 7(3), 207-227.

Swan, T.W. (1956). Economic growth and capital accumulation, Economic Record. 32, 334-361.

Tamilina, L., and Tamilina, N. (2014). Heterogeneity in Institutional Effects on Economic Growth: Theory and Empirical Evidence. European Journal of Comparative Economics. Cattaneo University (LIUC), 11(2), 205-249.

Tumusiime-Mutebile, E. (2010). Institutional and political dimensions of economic reform', in F. Kuteesa, TumusiimeMutebile, A. Whitworth and T. Williamson (eds.), Uganda's Economic Reforms, Insider Accounts. (pp.35-51). Oxford- Oxford University Press.

Valeriani, E. and Peluso, S. (2011), The impact of institutional quality on economic growth and development: empirical evidence', Journal of Knowledge Management, Economics and Information Technology. 6, 1-25.

Weil, D.N. (2008). Economic growth, Pearson, London.

William Easterly and Ross Levine (2001). It's Not Factor Accumulation: Stylized Facts and Growth Models. The World Bank Economic Review. 15(2). 177-219.

World Bank (2004). Uganda country procurement assessment report. Washington DC. World Bank.

Zouhair, H. (2012). Institutions, investment and economic growth. International Journal of Economics and Finance. 4(2), 152-162.

Citethis articleas: Olwor Sunday N icholas (2021). High performing institutions and economic development: A case study of Uganda. International Journal of M anagement Research and Economics. 1(1), 34-58. doi: 10.51483/ IJMRE.1.1.2021.34-58. 